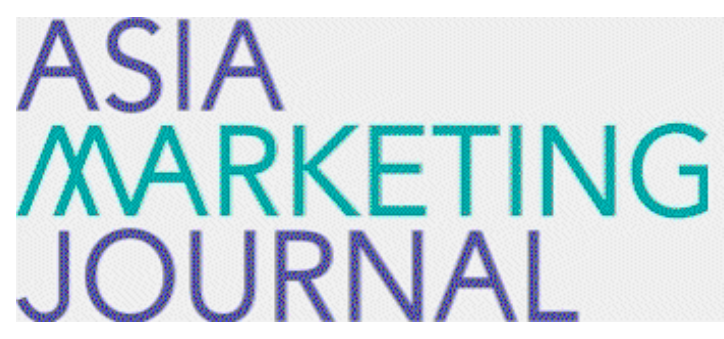

ASIA MARKETING JOURNAL

Volume 18 | Issue 2

Article 2

7-31-2016

\title{
Effects of Technology Readiness on User Perceptions and Use Intention of Mobile Social Commerce
}

Sang-Lin Han

Hyo-Ju Park

Follow this and additional works at: https://amj.kma.re.kr/journal

Part of the Marketing Commons

\section{Recommended Citation}

Han, Sang-Lin and Park, Hyo-Ju (2016) "Effects of Technology Readiness on User Perceptions and Use Intention of Mobile Social Commerce," Asia Marketing Journal: Vol. 18 : Iss. 2 , Article 2.

Available at: https://doi.org/10.15830/amj.2016.18.2.25

This Article is brought to you for free and open access by Asia Marketing Journal. It has been accepted for inclusion in Asia Marketing Journal by an authorized editor of Asia Marketing Journal. 


\title{
Effects of Technology Readiness on User Perceptions and Use Intention of Mobile Social Commerce
}

\author{
Sang-Lin Han* \\ Hyo-Ju Park**
}

This research was implemented by using TRAM model. An existing research (Ok 2011) which dealt with technology readiness and social commerce at once had only asked consumers' attitude on 'general technology'. This research, however, has specifically focused on Social Network Service and mobile social commerce. Research hypotheses and research model were developed and tested by using 610 consumer survey data.

It was found that individual's positive/negative technology readiness has a direct influence positively/ negatively on perceived ease of use and perceived trust respectively. Also their positive and negative technology readiness has an indirect influence positively/negatively on perceived usefulness. Thus someone's positive and negative attitude on SNS has a different direction towards the perception of mobile social commerce. Perception on mobile social commerce depends on their attitude (positive or negative) concerning SNS. Managerial implications and limitations of the study were also discussed.

Key words: Technology Readiness, SNS, User perception, Social commerce, TRAM

\section{Introduction}

Social commerce was selected as the most frequently used shopping site (DMC Media 2013). For this reason, Sports Seoul (2013) analyzed that social commerce has originally advantageous business model which can be used instantly when consumers purchase ticket (restaurant, esthetic and performance) and offer location-based service. Above this, National Information Society Agency (2010) suggested that the development concerning mobilization of Social Commerce will be needed, at the same time, the characteristic such as real time, mobility and location-based of mobile device

\footnotetext{
* Professor of Marketing, Hanyang University Business School, Korea (slhan@hanyang.ac.kr)

** Hanyang University Business School, Korea (p96521@hanyang.ac.kr)
} 
should be combined because Social Commerce has connection with SNS and Mobile.

Two issues as mentioned earlier are: 1) the popularization of mobile devices, 2) social commerce (which is the most successful retailer among mobile shoppings). Thus Mobile Social Commerce (MSC) which is a kind of combination Mobile and Social Commerce will be studied in this research. From the definition by Doopedia that Social Commerce is defined as 'the e-commerce throughout Social Network Service(SNS)', in this research, we tried to investigate how the readiness of SNS influence the user perception and use intention pertaining to Mobile Social Commerce.

TRAM is a combination of the TRI(Technology Readiness Index) suggested by Parasuraman (2000) and the TAM(Technology Acceptance Model) suggested by Davis et al.(1989). So we may examine at a time that personal technology readiness, technology acceptance behavior, and use intention through TRAM Model.

Secondly, there were many papers only looking for Social Commerce (Han et al. 2012, Kim and Park 2013, Kim et al. 2013, Liang and Turban 2012, Goo and Jang 2012, Jang et al. 2013, Shin 2013, Zhou et al. 2013). In this research, the connection between SNS and Social Commerce will be examined by inspecting SNS and Social Commerce simultaneously.

Third, there were insufficient researches concerning Mobile Social Commerce because Mobile Social Commerce has recently been introduced.
By looking into overall introduction and the extent of perception on MSC, future strategies are given at the last of the paper. If extending the scope of business, implications to other industry staffs who are aiming Mobile Commerce are also offered.

\section{Theoretical Background}

\subsection{Technology Readiness (TR)}

Concept of TR was supposed by Parasuraman (2000) for the first time. It was defined as "people's propensity to embrace and use new technologies for accomplishing goals in home life and at work". It is composed of 4 components. TR should be considered when developing technology based Self-Service-Technology(SST) (e.g. ATM). The extent to which how many customers are ready to technology and have willingness to using SST affects real using (Lin \& Hsieh 2007).

Optimism is defined as a belief which enables people to control their lives effectively and flexibly by using technology. Innovativeness is defined as a tendency to become a pioneer on a technology (Parasuraman). These two concepts could be combined as "Drivers" which respond positively on a technology. People who have high drivers tend to have high technology either, and they usually feel comfortable in us- 
ing new technology (Walczuch et al. 2007).

Discomfort is defined as "a perceived lack of control over technology and a feeling of being overwhelmed by it" and Insecurity is defined as a "disbelief of technology and skepticism about its ability to work properly"(Parasuraman 2000). Two factors are regarded "Inhibitors". People who have high inhibitors used to have usually low technology readiness. They tend to have a negative view on a technology, feel uncomfortable and ask surrounding people more frequently (Walczuch et al. 2007).

\subsection{An applied theory model: TRAM(Technology Readiness Acceptance Model)}

TAM and TR have come together to integrate TRAM, which is "a theory which explain how personal technology readiness can affect formation and use behavior about technology" (Oh et al. 2010). There may exist some delicate difference, for example, whereas TR only measure belief about 'general technology', TAM can measure usefulness and comfort about "specific technology system'. It is intuitionally regarded, however, that both of them deal with 'technology' in common (Lin et al. 2007). Also they revealed that TR is a causal leading variable affecting cognition of usefulness and ease of use, and then, they found a psychological mechanism 'TR $\rightarrow$ PEOU(Perceived Ease of Use) $\rightarrow$ PU (Perceived Usefulness) $\rightarrow$ UI(Use Intention)' by investigating perceived usefulness and perceived ease of use also affect intention to use $\mathrm{e}^{-}$-service. So when offering technology to customers, businesses should recognize personal technology readiness which can be used for basis of market segmentation.

Walczuch et al.(2007) also found that attitude about technology (i.e. optimism, innovativeness, discomfort, and insecurity) can affect cognition of usefulness and ease of use. More specifically, first, optimism has the largest effect on perceived usefulness and perceived ease of use. People who have high optimism are open-minded and positive about IT. Secondly, innovativeness had negative effects on perceived usefulness, contrary to expectations. Innovative people tend to be cautious and sharp to latest technology, so they usually have high expectation on the state-of-the-art technologies. Third, discomfort had a negative effect on perceived ease of use. They feel complicated and overwhelmed by the technology. Finally, insecurity had a negative effect on both perceived usefulness and perceived ease of use. They feel anxious about technology and do not feel comfortable nor useful. So they are reluctant to use technology as a result.

Oh et al. (2010) desired to enhance understanding of technology readiness and technology acceptance by grouping 2 factors rather than dividing 4 factors: positive factors(optimism and innovativeness) and negative factors(discomfort and insecurity). And in a research of 
Baek (2008), he used TRAM for analyzing customers' use intention for the airline kiosk. As a result, he found that customers' optimism, innovativeness, and insecurity could significantly affect to perceived usefulness, perceived ease of use, and use intention.

\subsection{Mobile Social Commerce (MSC)}

Kim and Kim(2011), meanwhile, defined MSC as the concept that share customers' shopping experience through existent social commerce via mobile devices in real time. They mentioned that when accessing social commerce by mobile phones, we would be served timely service using mobile's real time, fusion on and off-line commerce experience making use of locationbased service, and comfortable commerce experience closely connected with SNS in comparison with the past.

By the way, building a safe and convenient payment system for mobile shopping including MSC is considered as the most important task because it requires some discomfort works such as a complicated process for installing finance certificate or worrying about security problem in online payment (etnews 2013). In a research of Lai and Lai (2013), they insisted that mobile transaction businessmen have to strive for building customers' trust and pay attention to not only advertisement profit but also security maintenance costs, strategies for customers' privacy, and security policies enhancing cus- tomers' relief. Wu and Wang(2005) also mentioned that many customers still feel insecurity about privacy and transaction security although internet commerce has been carried out through broad realms. So these insecurity factors have interrupted the popularization of the mobile commerce.

\subsection{Cognitive factors of Mobile Social Commerce}

In this research, three constructs - Perceived Ease of Use, Perceived Usefulness, and Perceived Trust - are established as constructs formulating cognition of MSC. Perceived Ease of Use and Perceived Usefulness are based on TAM by Davis (1989). Another factor 'Perceived Trust' is especially added, because nowadays trust, security, and risk are dealt with as an important factor in internet electronic commerce, social commerce purchase, and mobile electronic commerce (Lai and Lai 2013; Wei et al. 2009; Jeong and Yoon 2013).

\subsubsection{Perceived usefulness}

Perceived usefulness is a subjective norm that using specific ICT system makes one's business performance enhance (Davis et al., 1989). Jeong \& Yoon(2013) found that there are some merits such as decreasing transaction costs to banks, feeling usefulness overall to customers, and economizing their time by using mobile bank- 
ing system. Wang et al.(2006) also found that perceived usefulness have a largest effect on use intention of mobile service like e-mail, onlinegame, online stock transaction, music, and animation download. Above this, Davis (1989), Davis et al.(1989), Gefen et al.(2003) studied that recognizing the technology usefully could affect to use information technology.

\subsubsection{Perceived Ease of Use}

Secondly perceived ease of use is the extent to which people expect to feel free from mental or physical efforts by using that technology (Davis et al., 1989). So if people feel free to technology, they will want to use that technology more and more (Venkatesh and Morris 2000). Jeong \& Yoon(2013) revealed that people who feel hard to use mobile banking service or learn way of utilization, they finally regarded mobile banking service as discomfort service. Like this, feeling comfortable to technology acts an important factor which determines whether use or not.

\subsubsection{Perceived Trust}

People using internet-based service tend to be worry about their name or password being hacked by someone or their online transaction going wrong (Jeong \& Yoon 2013). Schlosser et al. (2006) also found that trust and trustrelated concepts could be decisive factors af- fecting online purchase intention. In a research of Luarn and Lin(2005), they figured out when using mobile banking, trust have the biggest impact on use intention among ease of use, usefulness, trust, self-efficacy, and economic cost. Thus we may think gaining customers' trust in mobile social commerce is quite important from a financial transaction perspective.

\subsubsection{Use Intention of MSC}

According to TAM by Davis (1989), perceived ease of use and perceived usefulness of technology are connected by use intention of specific technology. After the study of TAM, there have been many researches on consumer's technology acceptance. Some mobile-applied researches out of them, for example, Luarn and Lin (2005) found that both perceived usefulness and perceived ease of use affect to the use intention. Jeong and Yoon(2013) mentioned both perceived usefulness and perceived ease of use about mobile banking can affect to use intention. To whom are favorable to mobile environment, especially, perceived ease of use have bigger effect on use intention. Hsiao et al. (2010) revealed that perceived trust which was suggested as another causal variable could be also connected by purchase intention under SNS or web site circumstance. Finally, Shin (2013) found that perceived trust would positively affect to use social commerce.

According to Zeithaml et al.(1996), a favor- 
able behavioral intention could be seen like these: 1) someone tend to tell positive word of mouth (Boulding et al. 1993), 2) someone tend to recommend to other customers (Parasuraman et al. 1991; Parasuraman et al. 1988), 3) someone tend to keep their loyalty (Rust \& Zahorik, 1993), 4) someone tend to buy bulk purchases or pay price premium (Zeithaml et al. 1996). Thus, positive intention to use goes with a positive intention to recommend to other people.

\section{Research Hypotheses and Model Development}

Oh et al. (2010) found that positive TR (optimism and innovativeness) could affect to perceived ease of use positively. So they insisted that when developing new products, it is important strategy to emphasize the ease of use and learning about mobile internet technology. They also found that negative TR such as discomfort and insecurity could negatively affect to perceived ease of use. Strategy which reduces resistance about discomfort or insecurity will be needed. Lin et al. (2007) verified that specific technology readiness tendency also could influence the recognition about the ease of use and usefulness on specific e-service. Walczuch et al. (2007) found that optimism is positively correlated with ease of use and usefulness respectively and innovativeness is positively correlated with ease of use and negatively correlated with usefulness. Also discomfort negatively affects ease of use and do not affect usefulness. Finally, insecurity is negatively correlated with ease of use and usefulness simultaneously. Based on this theoretical background, the following research hypotheses are established.

Hypothesis 1-1: Consumers' positive technology readiness on SNS is positively correlated with their perceived ease of use on Mobile Social Commerce.

Hypothesis 1-2: Consumers' positive technology readiness on SNS is positively correlated with their perceived usefulness on Mobile Social Commerce.

Hypothesis 2-1: Consumers' negative technology readiness on SNS is negatively correlated with their perceived ease of use on Mobile Social Commerce.

Hypothesis 2-2: Consumers' negative technology readiness on SNS is negatively correlated with their perceived usefulness on Mobile Social Commerce.

This research, meanwhile, is a extended model added another variable in addition to the perceived usefulness and perceived ease of use. The one is 'perceived trust'. There are many researches which added variable perceived enjoyment instead of perceived trust (Kang and Park 2011; Shin 2011). Social commerce businesses, in the introduction of business, used to 
attract their customers by mainly offering halfprice sale. Social commerce pursued only enjoyment, however, gave their customers side effects - distrust or discomfort. For example, there were quality differences between regular priced merchandises and social commerce merchandises. Or they made excessive profits by selling imitation products as genuine products

Fair Trade Commission in Korea (2010) eventually decided to issue 'consumer damage warning' to prevent them from additional damages. So each social commerce businesses are now trying to build customers' trust because distrust variables used to negatively affect to social commerce transaction. For example, Coupang is one of Korean social commerce company posted some promises to customers - "There are no differences among our service and products quality. Our all things are examined in required quality, country of origin, and a normal price." We Make Price, another social commerce company, is promoting to make customers relaxed by posting a certificate of import declaration picture by Korea Customs Service with the slogan "You may get a refund on it immediately if this parallel imports be turned out to be not a genuine." The reason why this study concentrate on trust differently from other studies is that trust is not only a significant variable which determine customers' behavior but also regarded as a crucial point under mobile marketing (Bauer et al. 2005). Also recent researches such as survival of social commerce is came from a mechanism which accelerate trust (Zhou et al. 2013), trust is a necessary requisite to attract and retain customers (Shin 2013), and trust perceived when given recommendation took a important role in raising purchase intention (Hsiao et al. 2010) show that the importance of trust is growing fast. Meanwhile, there was a study on people who consistently using and feeling contended with SNS used to feel Social commerce based SNS (Moon et al. 2012). On the contrary, insecurity element is known for one of variables affecting using IT (Sun and Zhang 2006). Hypotheses are established based on a study which found system insecurity affects negatively to honesty of $\mathrm{e}^{-}$ trust (Hwang and Kim 2007).

Hypothesis 1-3: Consumers' positive technology readiness on SNS is positively correlated with their perceived trust on Mobile Social Commerce.

Hypothesis 2-3: Consumers' negative technology readiness on SNS is negatively correlated with their perceived trust on Mobile Social Commerce.

According to Kim (2012), perceived usefulness could affect positively to purchase intention (use intention) when using mobile social commerce. Kang et al. (2006) found that perceived usefulness and ease of use could affect to use intention in case of mobile commerce. Kang and Park (2011) also verified that perceived useful- 
ness and perceived ease of use positively $(+)$ affect to use intention of online social shopping sites. When shopping via smart-phone, perceived usefulness could affect to intention to use shopping mall was found by Jung (2012). A research by Oh et al. (2010) is that perceived usefulness and perceived ease of use about mobile internet service would be connected by intention to use. In addition, Wu and Wang (2005) found that perceived usefulness would be connected by actual use through intention to use and perceived ease of use give a effect to intention to use through perceived usefulness rather than on their direct influence. Hypotheses are established through the above preceding researches.

Hypothesis 3: Consumers' perceptions of ease of use about a Mobile Social Commerce are positively correlated with their intentions to use it. Hypothesis 4: Consumers' perceptions of usefulness about a Mobile Social Commerce are positively correlated with their intentions to use it.

Meanwhile, Hsiao et al. (2010) found that perceived trust in web-site connected by actual intention to use, Shin (2013) also discovered the effect of trust in social commerce on purchase behavior is higher than prior researches (Buttner \& Goritz 2008). Davis(1989) revealed that perceived ease of use concerning technology positively affected to perceived usefulness in his TAM research. Lai and Lai(2013) also found that perceived ease of use strongly affected perceived usefulness, so did Oh et al. (2010) and Wu and Wang(2005). Shen(2010) found

\section{〈Figure 1〉 Proposed Research Model}

SNS-based Technology Readiness

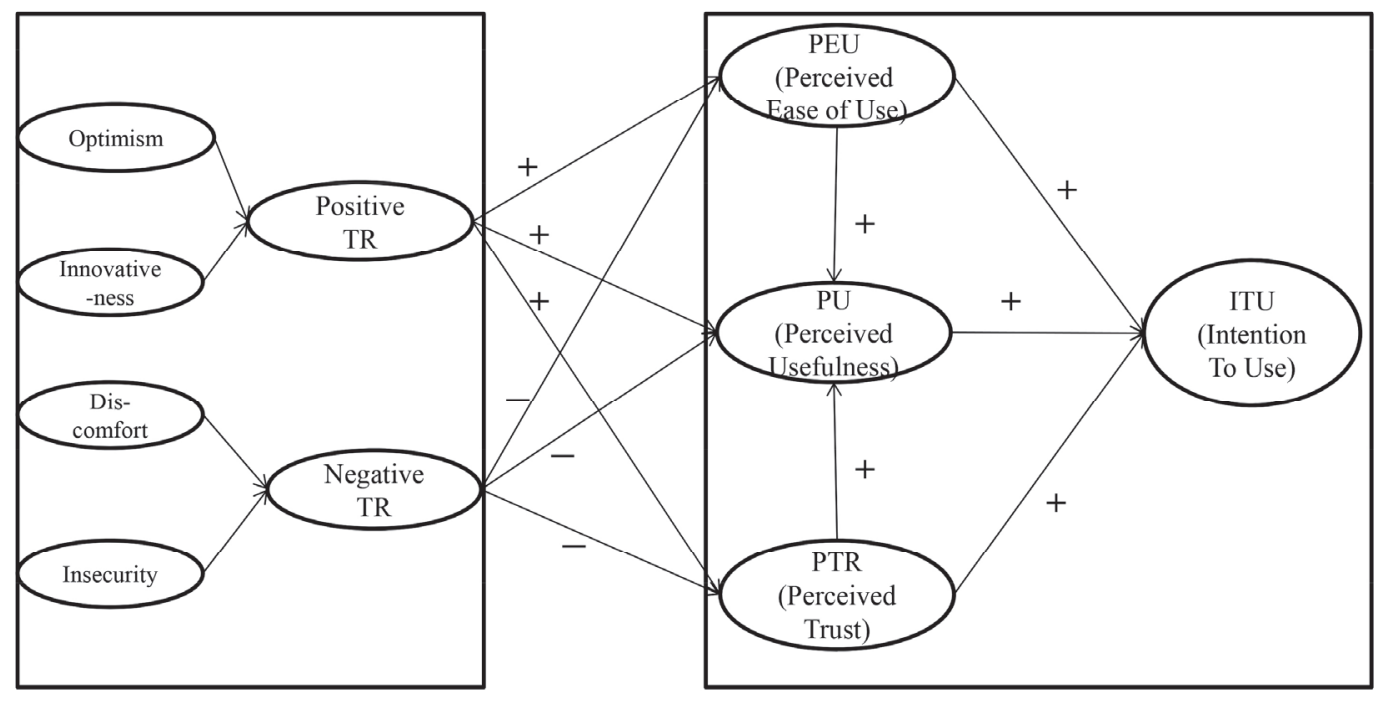

User Perceptions and Use Intention of MSC 
that perceived trust which was made in social commerce site could positively affect to perceived usefulness. Trust is regarded as crucial construct, thus, additional hypothesis is set. We have developed the following hypotheses.

Hypothesis 5: Consumers' perceptions of trust about a Mobile Social Commerce are positively correlated with their intentions to use it.

Hypothesis 6: Consumers' perceptions of ease of use about a Mobile Social Commerce are positively correlated with its perceptions of usefulness.

Hypothesis 7: Consumers' perceptions of trust about a Mobile Social Commerce are positively correlated with its perceptions of usefulness.

Based on the above hypotheses and theoretical background, the proposed research model was developed and figure 1 shows the model.

\section{Analysis of Research Model}

To test the research hypotheses and proposed research model, questionnaire survey was conducted in the city of Seoul, Korea. Total 610 samples were used for actual analysis, which were consist of 276 males (45.3\%) and $334 \mathrm{fe}^{-}$ males $(54.7 \%)$.

\subsection{Reliability of measurement}

To test the reliability and internal consistency of measurement, Cronbach's alpha coefficient was used to check. A factor named 'DCF1' of discomfort construct was deleted to improve reliability. As seen in the table 1 , the level of reliability is quite enough to accept.

〈Table 1〉 Result of reliability test (Cronbach's alpha)

\begin{tabular}{|c|c|c|c|c|}
\hline & \multirow[b]{2}{*}{ Constructs } & \multicolumn{2}{|c|}{ The number of Items } & \multirow[b]{2}{*}{ Cronbach's Alpha } \\
\hline & & $\begin{array}{c}\text { Before deleting } \\
\text { items }\end{array}$ & $\begin{array}{c}\text { After deleting } \\
\text { items }\end{array}$ & \\
\hline \multirow{2}{*}{ Positive TR } & Optimism & 4 & 4 & .814 \\
\hline & Innovativeness & 4 & 4 & .765 \\
\hline \multirow[t]{2}{*}{ Negative TR } & Discomfort & 4 & $\begin{array}{c}3 \\
\text { (DCF1 deleted) }\end{array}$ & .729 \\
\hline & Insecurity & 4 & 4 & .846 \\
\hline \multicolumn{2}{|c|}{ Perceived Ease of Use } & 4 & 4 & .912 \\
\hline \multicolumn{2}{|c|}{ Perceived Usefulness } & 4 & 4 & .813 \\
\hline \multicolumn{2}{|c|}{ Perceived Trust } & 5 & 5 & .832 \\
\hline \multicolumn{2}{|c|}{ Intention to Use } & 3 & 3 & .937 \\
\hline
\end{tabular}




\subsection{Validity Testing}

As seen in the table 2, to test the validity of measurement, CFA (Confirmatory Factor Analysis) was done to know that all constructs have adequately measured what we want to measure. Results are shown that $x^{2}=1478.398, \mathrm{df}=415$, $\mathrm{GFI}=.855, \mathrm{NFI}=.852, \mathrm{CFI}=.888, \quad \mathrm{RMSEA}=$ .065. Although indexes are little bit insufficient to criteria, we can accept the data to use the final analysis. Also, each AVE value of all constructs is exceeded the standard (.50).

\subsection{Model and Hypotheses Testing}

Proposed research model was tested by using structural equation model and AMOS to identify how TR based SNS affects to user perception and use intention of MSC. The results are shown in the table 3. Model goodness of fit was satisfied and we could accept our proposed research model.

Based on the results of analyses, total 11 hypotheses are examined.
Hypothesis 1-1: Consumers' positive technology readiness on SNS is positively correlated with their perceived ease of use on Mobile Social Commerce.

A result indicated that Estimate $=.792$, S.E. $=.220$, C.R. $(\mathrm{t}$-value $)=6.928$, and $\mathrm{p}<.001$. So $\mathrm{H}$ 1-1 was supported. That is, positive attitude concerning SNS technology (optimism and innovativeness) is positively $(+)$ correlated with perceived ease of use. Especially, 4 questions of optimism (OPT1: SNS gives people more control over their daily lives., OPT2: SNS is much more convenient to use., OPT3: I like SNS activity because you are not limited to regular business hours. and OPT4: SNS makes me more efficient in your occupation.) are quite enough to reflect the meaning of 'ease of use'.

Hypothesis 1-2: Consumers' positive technology readiness on SNS is positively correlated with their perceived usefulness on Mobile Social Commerce.

A result indicated that Estimate $=-.004$, S.E.

〈Table 2〉 Results of Confirmatory Factor Analysis of Measurement

\begin{tabular}{cccccccc}
\hline Criteria & $x^{2}$ & $\mathrm{df}$ & GFI & NFI & CFI & RMSEA & P-value \\
\hline Model & 1478.398 & 415 & .855 & .852 & .888 & .065 & .000 \\
\hline
\end{tabular}

〈Table 3〉 Goodness-of-fit of the Research Model

\begin{tabular}{cccccccccc}
\hline & $x^{2}$ & df & $x^{2} / \mathrm{df}$ & GFI & AGFI & CFI & RMSEA & NFI & p-value \\
\hline Value & 1014.457 & 385 & 2.635 & .902 & .873 & .934 & .052 & .898 & .000 \\
\hline
\end{tabular}


$=.354$, C.R. $(\mathrm{t}$-value $)=-.022$, and $\mathrm{p}=.983$. So $\mathrm{H}$ 1-2 was rejected because it is not statistically significant. When it comes to think why hypothesis is rejected, people tend to go to major supermarkets or department stores directly and instantly when they need daily goods or under urgent situation. Products from mobile social commerce, however, mainly focus on impulse shopping goods or instantly available voucher till now.

Hypothesis 1-3: Consumers' positive technology readiness on SNS is positively correlated with their perceived trust on Mobile Social Commerce.

A result indicated that Estimate $=.684$, S.E. $=.183$, C.R. $(\mathrm{t}$-value $)=7.016$, and $\mathrm{p}<.001$. So $\mathrm{H}$ 1-3 was supported from its statistical significance. In many mobile social commerce applications, they have officially posted messages like "There are no differences among our service and products quality. Our all things are examined in required quality, country of origin, and a normal price." or "You may get a refund on it immediately if this parallel imports be turned out to be not a genuine."in order to raise customers's trust. Thus, favorable attitude on SNS is positively correlated with formation of trust of Mobile Social Commerce.

Hypothesis 2-1: Consumers' negative technology readiness on SNS is negatively correlated with their perceived ease of use on Mobile Social Commerce.

$\mathrm{A}$ result indicated that Estimate $=-.119$, S.E. $=.102$, C.R. $(\mathrm{t}$-value $)=-2.130$, and $\mathrm{p}<.05$. So $H$ 2-1 was supported from its statistical significance. Negative TR consists of discomfort and insecurity. Especially, 3 discomfort questions (DCF2: There is no such thing as a manual for a SNS that is written in plain language., DCF3: If I use a high-tech SNS, I prefer to have the basic function over one with a lot of extra features., DCF4: There should be caution in replacing important people-tasks with SNS because SNS can breakdown or get disconnected.) reflect the contrary of perceived ease of use. Because mobile social commerce is upper concept of SNS, of course, negative attitude on SNS can influence negative cognition of SNS.

Hypothesis 2-2: Consumers' negative technology readiness on SNS is negatively correlated with their perceived usefulness on Mobile Social Commerce.

A result indicated that Estimate $=.075$, S.E. $=.123, \mathrm{C} . \mathrm{R} .(\mathrm{t}$-value $)=1.13$, and $\mathrm{p}=.266$. So $\mathrm{H}$ 1-2 was rejected. That is, negative TR on SNS has no relation with perceived usefulness. It hasn't been that long since mobile social commerce was introduced. So there was insufficient time to experience MSC. In addition, negative attitude about SNS is hard to be connected to- 
ward the mobile social commerce which is advanced service of SNS.

Hypothesis 2-3: Consumers' negative technology readiness on SNS is negatively correlated with their perceived trust on Mobile Social Commerce.

A result indicated that Estimate $=-.370$, S.E. $=.129$, C.R. $(\mathrm{t}$-value $)=-5.101$, and $\mathrm{p}<.001$. So H 2-3 was supported from its statistical significance. Negative TR contains 'Discomfort' and 'Insecurity'. Especially, questions of insecurity consist of "You do not consider it safe giving out a credit card number or resident registration number over a SNS(ISC1)", "You worry that information you send over the SNS will be seen by other people(ISC3)" and "If you provide information over the SNS, you can never be sure it really gets to right place (ISC4)". It reflects a state of disbelief. Thus, these negative attitude are negatively related with perceived trust.

Hypothesis 3: Consumers' perceptions of ease of use about a Mobile Social Commerce are positively correlated with their intention to use it.

A result indicated that Estimate $=.236$, S.E. $=.162$, C.R. $(\mathrm{t}$-value $)=-2.134$, and $\mathrm{p}<.05$. So $\mathrm{H}$ 3 was supported from its statistical significance. When people think a system of comfort, they tend to use continuously. Like this, perceived ease of use about MSC is positively related in- tention to use MSC.

Hypothesis 4: Consumers' perceptions of usefulness about a Mobile Social Commerce are positively correlated with their intention to use it.

A result indicated that Estimate $=.399$, S.E. $=.214$, C.R. $(\mathrm{t}$-value $)=2.700$, and $\mathrm{p}<.05$. So $\mathrm{H}$ 4 was supported from its statistical significance. That is, perceived usefulness of MSC is positively related with intention to use it. MSC can provide customers with price benefit, economy of time and achievement of shopping goal. So customers have intention to use MSC, in addition, purchase continuously.

Hypothesis 5: Consumers' perceptions of trust about a Mobile Social Commerce are positively correlated with their intention to use it.

A result indicated that Estimate $=.235$, S.E. $=.102$, C.R. $(\mathrm{t}$-value $)=3.461$, and $\mathrm{p}<.001$. So H5 was supported from its statistical significance. It is revealed that perceived trust on MSC have positive relationship with intention to use MSC. MSC is a concept of money transaction and if perception on trust is fulfilled, people can believe MSC process. Thus, they have intention to use MSC finally.

Hypothesis 6: Consumers' perceptions of ease of use about a Mobile Social Commerce are positively correlated with its perceptions of usefulness. 
A result indicated that Estimate $=.640$, S.E. $=.123$, C.R. $(\mathrm{t}$-value $)=5.270$, and $\mathrm{p}<.001$. So $\mathrm{H}$ 6 was supported from its statistical significance. Using and thinking mobile social commerce as comfortable indicates they can deal with MSC skillfully. They can achieve purpose of shopping at the same time, so it is possible for them to feel useful.

Hypothesis 7: Consumers' perceptions of trust about a Mobile Social Commerce are positively correlated with its perceptions of usefulness.

A result indicated that Estimate $=.384$, S.E. $=.107$, C.R. $(\mathrm{t}$-value $)=3.716$, and $\mathrm{p}<.001$. So $H$ 7 was supported from its statistical significance. Mutual cohesion can arise when people trust each other. Like mobile social commerce, when customers trust mobile social commerce businesses, they have expectation on getting products or service which I purchased on time. Also particulars of payment could be handled ex-

$\langle$ Table 4〉 Results of Hypotheses testing

\begin{tabular}{|c|c|c|c|c|c|c|}
\hline & Path & Esti-mate & S.E. & $\begin{array}{l}\text { C.R. } \\
\text { (t값) }\end{array}$ & $\mathrm{P}$-value & Conclusion \\
\hline \multirow{5}{*}{$\begin{array}{l}\mathrm{D} \\
\mathrm{I} \\
\mathrm{R} \\
\mathrm{E} \\
\mathrm{C} \\
\mathrm{T}\end{array}$} & $\begin{array}{l}\text { Hypothesis 1-1 } \\
\text { Positive TR } \rightarrow \text { Perceived Ease of Use }\end{array}$ & .792 & .220 & 6.928 & $* * *$ & Supported \\
\hline & $\begin{array}{l}\text { Hypothesis } 1-2 \\
\text { Positive TR } \rightarrow \text { Perceived Usefulness }\end{array}$ & -.004 & .354 & -.022 & .983 & Rejected \\
\hline & $\begin{array}{l}\text { Hypothesis } 1-3 \\
\text { Positive TR } \rightarrow \text { Perceived Trust }\end{array}$ & .684 & .183 & 7.016 & $* * *$ & Supported \\
\hline & $\begin{array}{l}\text { Hypothesis 2-1 } \\
\text { Negative TR } \rightarrow \text { Perceived Ease of Use }\end{array}$ & -.119 & .102 & -2.130 & $* *$ & Supported \\
\hline & $\begin{array}{l}\text { Hypothesis } 2-2 \\
\text { Negative TR } \rightarrow \text { Perceived Usefulness } \\
\end{array}$ & .075 & .123 & 1.113 & .266 & Rejected \\
\hline \multirow{4}{*}{$\begin{array}{l}\mathrm{E} \\
\mathrm{F} \\
\mathrm{F} \\
\mathrm{E} \\
\mathrm{C} \\
\mathrm{T}\end{array}$} & $\begin{array}{l}\text { Hypothesis 2-3 } \\
\text { Negative TR } \rightarrow \text { Perceived Trust }\end{array}$ & -.370 & .129 & -5.101 & $* * *$ & Supported \\
\hline & $\begin{array}{l}\text { Hypothesis } 3 \\
\quad \text { Perceived Ease of Use } \rightarrow \text { Use Intention }\end{array}$ & .236 & .162 & 2.134 & $* *$ & Supported \\
\hline & $\begin{array}{l}\text { Hypothesis } 4 \\
\quad \text { Perceived Usefulness } \rightarrow \text { Use Intention }\end{array}$ & .399 & .214 & 2.700 & $* *$ & Supported \\
\hline & $\begin{array}{l}\text { Hypothesis } 5 \\
\quad \text { Perceived Trust } \rightarrow \text { Use Intention }\end{array}$ & .235 & .102 & 3.461 & $* * *$ & Supported \\
\hline \multirow{2}{*}{$\begin{array}{c}\text { In- } \\
\text { direct } \\
\text { Effect }\end{array}$} & $\begin{array}{l}\text { Hypothesis } 6 \\
\quad \text { Perceived Ease of Use } \rightarrow \text { Perceived Usefulness }\end{array}$ & .640 & .123 & 5.270 & $* * *$ & Supported \\
\hline & $\begin{array}{l}\text { Hypothesis } 7 \\
\quad \text { Perceived Trust } \rightarrow \text { Perceived Usefulness }\end{array}$ & .384 & .107 & 3.716 & $* * *$ & Supported \\
\hline
\end{tabular}


SNS based TR

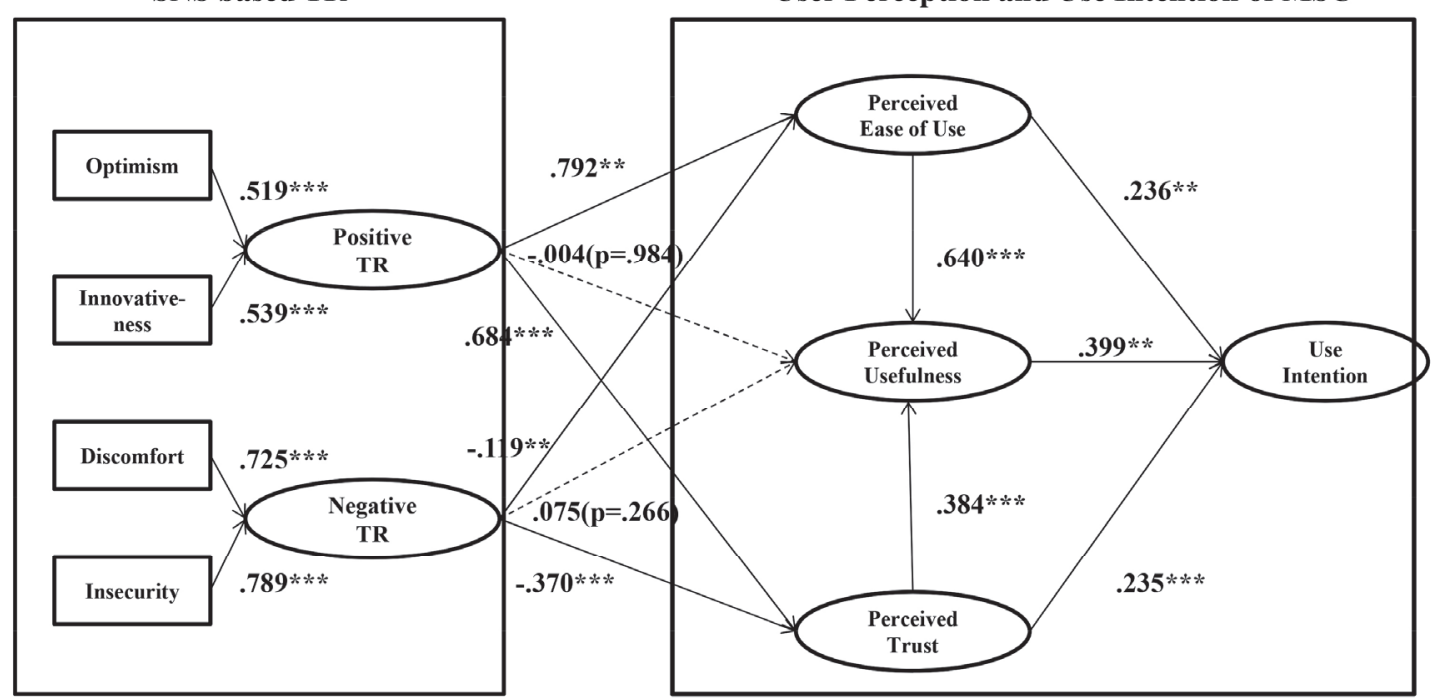

actly and securely, so they can perceive usefulness about mode of transaction.

Final Model is shown in the Figure 2 according to whether hypothesis is supported or not.

\section{Conclusion and Implication}

The results and findings of the present study suggest both theoretical and practical implications.

\subsection{Theoretical implication}

First, this research was implemented by using TRAM model. TRAM is regarded useful when examining one's Technology Readiness and Attitude on technology at once. But a few researches was got a write-up in Lin et al. (2007), Walczuch et al.(2007), Baek (2008), and Oh et al.(2010). So this study is considered one of the success researches trying to investigate TRAM.

Second, an existing research (Ok 2011) which dealt with technology readiness and social commerce at once had only asked consumers' attitude on 'general technology'. This research, however, has lightened specially the SNS and mobile social commerce. That is, the connection between social commerce and SNS that is an upper concept of social commerce was more directly focused on. It was found that individual's positive/negative technology readiness has a direct influence positively/negatively on perceived ease of use and perceived trust respectively. Also their positive and negative technology 
readiness has an indirect influence positively/ negatively on perceived usefulness. Thus someone's positive and negative attitude on SNS has a different direction towards the perception of mobile social commerce. Perception on mobile social commerce depends on their attitude (positive or negative) concerning SNS.

\subsection{Managerial Implication}

First, many distributors dealing with social commerce such as department stores, major supermarkets, and online shopping malls) focus on not a web but a mobile. It is also anticipated that the applied scope of the mobile social commerce will be extended. Thus, it would be a meaningful study to whom may wish to success in mobile shopping market,.

Second, availability of SNS as word-of-mouth has been proved long time ago. In a research of Han et al. (2012), they suggested that characteristic of word-of-moth and recommendation using SNS in social commerce is very important, so future research has to focus on them. It was confirmed that consumers' use intention including recommendations in mobile social commerce was very high. That means people who take of mobile social commerce tend to spread positive word-of-mouth, so it will be good marketing instrument for customers to provide technology service which enable to have positive word-ofmouth via SNS. Sine qua non for this is $\mathrm{se}^{-}$ lecting customers having positive attitude on
SNS technology.

Third, it was revealed that customers feel convenient and trust on mobile social commerce but do not feel usefulness. In order to make them feel useful about mobile social commerce, an effort to broaden assortment will be needed.

\subsection{Limitations and Further Research Suggestions}

The present study indicated some limitations of the research and directions for future research. First, this research intended to whom have already used SNS. However it will be more meaningful research to examine people who use now mobile social commerce and web-based social commerce either (e.g. What brings them to mobile from web?). It is also possible that the comparison among people who used to take web-based social commerce but don't use mobile social commerce (e.g. Why don't they use mobile social commerce?). For example, mobile device is not only more light and portable than computer but also provided locate-based services. But small display and complexity such as installing financial certificate are some disadvantages of mobile commerce. Thus, future researches about verifying their detail reasons will be needed. Furthermore, this study relies on young people. All ages were not distributed evenly. 20 aged and 30 aged especially covered $84.8 \%$. Like many similar studies dealing with IT, this study focused on electronic devices (smart phones, 
tablet PCs) and latest internet technology (SNS, mobile social commerce). However, the era of mobile will be diffused faster than now, and convenient service will be unveiled rapidly. Thus, it will be meaningful if future research aim at middle-aged group, and then, a researcher can extract representative characteristics by comparing young aged group and middle aged group.

〈Received July 12. 2016〉

〈Accepted August 3. 2016〉

\section{References}

Ahn, Dong-Keun. (2012), “An Influence of Characteristics of Social Commerce and SNS Use on Consumer's Purchase Intention," Journal of Korean Society of Communication Design, 19, 219-232.

Ajzen, I. and Fishbein, M. (1980), "Understanding attitudes and predicting social behavior," Englewood Cliffs, NJ: Prentice-Hall.

Bauer, Hans H., Barnes, Stuart J., Tina Reichardt and Marcus M. Neumann. (2005), "DRIVING CONSUMER ACCEPTANCE OF MOBILE MARKETING: A THEORETICAL FRAMEWORK AND EMPIRICAL STUDY," Journal of Electronic Commerce Research, 6(3), 181-192.

Boulding, W., Kalra, A., Staelin, R., and Zeithaml, V. A. (1993). "A dynamic process model of service quality: from expectations to behavioral intentions." Journal of Marketing Research, 30(1), 7-27.

Buttner, O. and Goritz, A. S. (2008), "Perceived trustworthiness of online shops," Journal of Consumer Behavior, 7, 35-50.

Davis, F. D. (1989). Perceived Usefulness, Perceived Ease of Use, and User Acceptance of Information Technology. MIS Quarterly, 13(3), 318-339.

Davis, F. D., Bagozzi, R. P. and Warshaw, P. R. (1989), "User Acceptance of Computer Technology: A Comparison of Two Theoretical Models." Management Science, 35(8), 983-1003.

Demaray, M. K. and Malecki, C. K. (2002), "Critical levels of perceived social support associated with student adjustment," School Psychology Quarterly, 17 (3), 213-241.

DMC Media (2013), "Report of utilization of mobile shopping".

Doney, P. M. and Cannon, J. P. (1997), “An examination of the nature of trust in buyer-seller relationships," Journal of Marketing, 61 (2), 35-51.

Fishbein, M., \& Ajzen, I. (1975), "Belief, attitude, intention and behavior: An introduction to theory and research." Reading, MA: Addison-Wesley.

Gefen, D., Karahanna, E., \& Straub, D. W. (2003), "Trust and TAM in Online Shopping: An Integrated Model," MIS Quarterly, 27(1), 51-90.

Ghani, N. A. and Sidek, Z. M.(2008), "Personal 
Information and Privacy in E-Commerce Application," Proceedings of the 7th WSEAS International Conference on INFORMATION SECURITY and PRIVACY, 28-32.

Han, Sang-Lin., Kim, Jun-Seong., Lee, BangHyeong., Kim, Seung-Si. and Lee, SungHoon. (2012), "Influence of Attitude toward Social-Commerce on Usage and Intention to Word-of Mouth," Korea Academy of Commodity Science \& Technology, 30(7), 161-175.

Han, Seo-hyoung., Kim, Yong-won. and Lee, Bong-Gyou. (2011), "The Effects of Characteristics of Social Commerce on Purchase Intention - Focusing on the Moderating Effect of Social Network Service," Korean Society for Internet Information, 12(6), 171-187.

Hsiao, Kuo-Lun., Judy, Chuan-Chuan Lin., Xiand-Ying Wang and Hsi-Peng Lu. and Hueiju Yu (2010), “Antecedents and consequences of trust in online product recommendations: An empirical study in social shopping," Online Information Review, 34(6), 935-953.

Hwang, Yujong and Kim, Dan J.(2007), “Customer self-service systems: The effects of perceived Web quality with service contents on enjoyment, anxiety, and e-trust," Integrated Decision Support Systems, 43(3), 746-760.

Jeong, B. K. and Yoon, T. E. (2013), “An Empirical Investigation on Consumer Ac- ceptance of Mobile Banking Services," Business and Management Research, 2(1), $31-40$.

Jia Shen (2012), "Understanding User's Acceptance of Social Shopping Websites: Effects of Social Comparison and Trust," Enterprise Information Systems Lecture Notes in Business Information Processing, 102, 365-373.

Jung, Won-Jin (2012), "The Effects of Usability of Mobile Shopping Malls on Customers' Intention to Buy," Korean Journal of Business Administration, 25(3), 1769-1791.

Jung, Won-jin. and Chung, Suk-kyun (2012), “The Effects of Smartphone Users' Perceptions of Information Security on Their Intention to Use Mobile Shopping Malls," Korean Corporation Management Review, 19(4), 261-282.

Kang, Seong-Soo, Kim, Ju-An. and Kim, Bak-Ho. (2006), "Factors Affecting on Users' Intention in using Mobile Commerce," JIEB, 19(3), 931-950.

Kang, You-Rie. and Park, Choel. (2011), "Factors influencing acceptance of online social shopping site," Korea IT Service Society, 10(1), 1-20.

Kim, Gi-Su (2012), "The Effects of Enjoyment, Contextual Information, Usefulness and Time in Mobile Social Commerce on the Intention of Purchase," Yonsei University.

Kim, Hyeon-Kyoung, and Kim, Seung-in (2011), "A case study on service characteristics of 
mobile social commerce-Focus on Groupon and LivingSocial-," Korea Design Knowledge Society, 62-71.

Kim, Sung-Bum., Sun, Kyung-A and Kim, Dae-Young. (2013), "The Influence of Consumer Value-Based Factors on AttitudeBehavioral Intention in Social Commerce: The Differences between High- and LowTechnology Experience Groups," Journal of Travel \& Tourism Marketing, 30, 108125.

Korea Communications Commission (2013), "Communications Commission in 2012 Annual Report”.

Korea Communications Commision and Korea Internet \& Security Association (2013), "Smartphone use survey by the second half of 2012".

Korea On-Line Shopping Association (2013), "2013 Understanding and Perspective of Online Shopping Market".

Lai, Ivan K. W. and Lai, Donny C.F. (2013), "User acceptance of mobile commerce: an empirical study in Macau," International Journal of Systems Science, 1-11.

Lam, Shun Yin., Chiang, Jeongwen., and Parasuraman, A.(2008) "The effects of the dimensions of technology readiness on technology acceptance: An empirical analysis," Journal of Interactive Marketing, 22(4), 19-39.

Lee, Thae-Min. and Lee, Eun-Young (2012), "A Study on the Determinants of Purchase
Intention in Mobile Commerce: Focused on the Mediating Role of Perceived Rrisks and Perceived Benefits," Asia Pacific Journal of Information Systems, 15 (2), 1-21.

Liang, T. P. and Turban, E. (2012), "Introduction to the Special Issue Social Commerce: A Research Framework for Social Commerce," International Journal of Electronic Commerce, 16(2), 5-13.

Lin, C. H., Shih, H. Y. and Sher, P.J. (2007), "Integrating Technology Readiness into Technology Acceptance: The TRAM Model," Psychology \& Marketing, 24(7), 641-657.

Lin, J. S. Chris., and Hsieh, P. L. (2007), "The influence of technology readiness on satisfaction and behavioral intentions toward self-service technologies," Computers in Human Behavior, 23(3), 1597-1615.

Liu, Chang., Marchewka, Jack T., Lu, June. and Yu, Chun-Sheng. (2004), "Beyond concern: a privacy-trust-behavioral intention model of electronic commerce," Information \& Management, 42(1), 127-142.

Luarn, P. and Lin, H. H. (2005), “Toward an Understanding of the Behavioral Intention to Use Mobile Banking." Computers in Human Behavior, 21(6), 873-891.

Mathieson, K., Peacock, E. and Chin, W.W. (2001). "Extending the Technology Acceptance Model: The Influence of Perceived User Resources." ACM SIGMIS Database, 32(3), 86-112.

Mattila, M. (2003), "Factors Affecting The 
Adoption Of Mobile Banking Services," Journal of Internet Banking and Commerce, 8(1), 149-160.

Moon, Jong-Beom., Kim, In-sub. and Jung, Won-Jun. (2012), “A Study on the Effect of SNS Satisfaction on the Reliability and Continuous Use of Social Commerce," Journal of the Korea Management Engineers Society, 17(2), 273-292.

National Information Society Agency (2010), "[IT \& Future Strategy no. 15] Emerging and future prospects of social commerce".

Oh, Jong-Chul., Yoon, Sung-Joon. and Yuen Wu., (2010), "A Study on Factors of Intention toward Using Mobile Internet Service: Revised TRAM," Service Management Society, 11(5), 127-148.

Ok, La-Mi. (2011), "The effects of technology readiness on the usage intention of social shopping," Master Thesis, Hanyang University.

Parasuraman, A. (2000), "Technology Readiness Index(TRI); A Multiple-Item scale to measure readiness to embrace new technologies," Jounal of Service Research, 2(4), 307-320.

Parasuraman, A., Berry, L. L., and Zeithaml, V. A. (1991), "Refinement and reassessment of the SERVQUAL scale," Journal of Retailing, 67(4), 420-450.

Parasuraman, A., Zeithaml, V. A., \& Berry, L. L. (1988), "SERVQUAL: A multiple-item scale for measuring consumer perceptions of service quality," Journal of Retailing,
64(1), 12-40.

Park, N. (2010), "Adoption and Use of ComputerBased Voice Over Internet Protocol Phone Service: Toward an Integrated Model," Journal of Communication, 60: 40-72.

Pavlou, Paul A .(2002), "Institution-based trust in interorganizational exchange relationships: the role of online B2B marketplaces on trust formation," The Journal of Strategic Information Systems, 11(3-4), 215-243.

Rust, R. T., and Zahorik, A. J. (1993), "Customer satisfaction, customer retention, and market share," Journal of Retailing, 69(2), 193-215.

Schlosser, Ann E., Tiffany B. White. and Susan M. Lloyd (2006), "Converting Web Site Visitors into Buyers: How Web Site Investment Increases Consumer Trusting Beliefs and Online Purchase Intentions," Journal of Marketing, 70(2), 133-148.

Shin, D. H. (2013), "User experience in social commerce: in friends we trust," Behaviour \& Information Technology, 32(1), 52-67.

Shin, You-Min. (2011), "Effect of technology readiness and personal involvement on the adoption process of innovative products", Hanyang University.

SK Telecom Customer Lifecycle Management (2013).

Sun, Heshan. and Zhang, Ping. (2006), "The role of moderating factors in user technology acceptance," International Journal of HumanComputer Studies, 64(2), 53-78.

Venkatesh, V. and Morris, M. G. (2000), "Why 
don't men ever stop to ask for directions? Gender, social influence, and their role in technology acceptance and usage behavior.," MIS Quarterly, 24(1), 115-139.

Walczuch, Rita., Lemmink, Jos. and Streukens, Sandra. (2007), "The effect of service employees' technology readiness on technology acceptance," Information \& Management, 44(2), 206-215.

Wang, Y. S., Lin, H. H. and Luarn, P. (2006), "Predicting Consumer Intention to Use Mobile Service," Information Systems Journal, 16(2), 157-179.

Wei, T. T., Marthandan, G., Chong, A.Y.L., Ooi, K. B., and Arumugam, S. (2009), "What Drives Malaysian m-Commerce Adoption? An Empirical Analysis', Industrial Management and Data Systems, 109, 370-388.
Wu, J. H. and Wang, S. C. (2005), "What drives mobile commerce? An empirical evaluation of the revised technology acceptance model," Information \& Management, 42, 719-729.

Zeithaml, V. A., Berry, L. L. and Parasuraman, A. (1996), "The behavioral consequences of service quality," Journal of Marketing, 60(2), 31-46.

Zhou, L., Zhang, P. and Zimmermann, HansDieter. (2013), "social commerce research: an integrated view," Electronic Commerce Research and Applications, 12(2), 61-68.

Zimet, Gregory D., Powell, Suzanne S., Farley, Gordon K., Sidney Werkman and Karen A. Berkoff (1990), "Psychometric characteristics of the multidimensional scale of perceived social support," Journal of Personality Assessment, 55, 610-617. 